\title{
Bazı Yerel Makarnalık Buğday Çeşitlerinde Küllemeye (Blumeria graminis f. sp. tritici) Karşı Dayanıklılığın Belirlenmesi
}

\author{
Özlem Ateş Sönmezoğlu 1*, Ahmet Yıldırım², Ümmühan Türk ${ }^{3}$, Yusuf Yanar ${ }^{4}$ \\ ${ }^{1}$ Karamanoğlu Mehmetbey Üniversitesi, Mühendislik Fakültesi, Biyomühendislik Bölümü, Karaman, (ORCID: 0000-0002-3423-7095) \\ ${ }^{2}$ Uluslararası Saraybosna Üniversitesi, Genetik ve Biyomühendislik Bölümü, Sarajevo, Bosnia and Herzegovina \\ ${ }^{3}$ Gaziosmanpaşa Üniversitesi, Ziraat Fakültesi, Tarla Bitkileri Bölümü, Tokat \\ ${ }^{4}$ Gaziosmanpaşa Üniversitesi, Ziraat Fakültesi, Bitki Koruma Bölümü, Tokat
}

(İlk Geliş Tarihi 14 Kasım 2019 ve Kabul Tarihi 13 Aralık 2019)

(DOI: 10.31590/ejosat.646712)

ATIF/REFERENCE: Sönmezoğlu, Ö. A., Yıldırım, A., Türk, Ü. \& Yanar, Y. (2019). Bazı Yerel Makarnalık Buğday Çeşitlerinde Küllemeye (Blumeria graminis f. sp. tritici) Karşı Dayanıklılı̆ıın Belirlenmesi. Avrupa Bilim ve Teknoloji Dergisi, (17), 944-950.

\section{$\ddot{O} \mathbf{z}$}

Buğdayın verim ve kalitesini olumsuz yönde etkileyen en önemli hastalıklardan birisi Blumeria graminis $\mathrm{f}$. sp. tritici'nin neden olduğu külleme hastalığıdır. Külleme, bahar döneminde nemin en yüksek olduğu bölgelerde sık görülen, ekonomik olarak ilaçlı mücadelesi olmayan bir hastalıktır.

Makarnalık buğdayın önemli gen kaynaklarından olan bazı yerel makarnalık buğday çeşitlerinin küllemeye karşı dayanıklılıklarının belirlenmesi amacıyla yürütülen bu araştırmada, Türkiye'nin farklı bölgelerden toplanmış olan 49 adet yerel makarnalık buğday çeşidi ve kontrol amacıyla Çeşit 1252, Gediz 75, Bezostaja, Tahirova-2000 ve Sofu çeşitleri kullanılmıştır. Farklı lokasyonlardan toplanan ve Türkiye'deki muhtemel ırkları temsil eden külleme sporları ile inoküle edilmiş yerel çeşitlerin hastalığa karşı gösterdikleri reaksiyon tipleri belirlenmiştir. Sonuç olarak küllemeye karşı bir yerel çeşidin (TR 31729) tek gen dayanıklılığına sahip olduğu tespit edilmiştir.

Anahtar Kelimeler: Makarnalık Buğday, Triticum durum, Yerel Çeşit, Külleme, Blumeria graminis, Dayanıklılık.

\section{Identification of Powdery Mildew (Blumeria graminis f. sp. tritici) Resistance in Some Durum Wheat Landraces}

\begin{abstract}
One of the most important diseases of wheat affecting yield and quality negatively is powdery mildew. It is seen very often in spring in regions with high humiditiy and using pesticides to control the disease is not economical.

In this study, 49 durum wheat land races collected from different regions of Turkey were used. In addition, five registered wheat cultivars (Çeşit-1252, Gediz-75, Bezostaja-1, Tahirova-2000 and Sofu) were used as controls. Reaction types of the land races infected with a collection of powdery mildew spores obtained from different locations and representing possible races of the pathogen were determined. As a result, only one land race (TR 31729), was found to have race specific resistance.
\end{abstract}

Keywords: Durum Wheat, Triticum durum, Land Race, Powdery Mildew, Erysiphe graminis, Resistance.

\footnotetext{
* Sorumlu Yazar: Karamanoğlu Mehmetbey Üniversitesi, Mühendislik Fakültesi, Biyomühendislik Bölümü, Karaman, Türkiye, ORCID: 0000-00023423-7095, ozlemsonmezoglu@kmu.edu.tr
} 


\section{Giriş}

Nüfus artışına bağlı olarak, insan beslenmesi yönünden gerekli bitkisel ve hayvansal gıdalara olan gereksinim hızlı bir şekilde artmaktadır. Bu bağlamda tahıllar özellikle de buğday önemli bir yere sahiptir. Ekiliş alanı ve üretim miktarı bakımından tahıllar içerisinde buğday (Triticum aestivum L., Triticum durum L.) birinci sırada yer almaktadır (Geçit ve ark. 2009).

Buğday dünyada yaklaşık 225 milyon hektar ekim alanına ve 736 milyon ton üretime sahiptir (USDA 2017). Dünyada buğday üretimine ayrılan alanın yaklaşık \%8-10'unda makarnalık buğday yetiştirilmektedir. Ülkemizde buğday yetiştirilen 7,9 milyon hektarlık alanda yaklaşık 19,5 milyon ton üretim yapılmaktadır (USDA 2017). Dünya makarnalık buğday üretiminde (40.7 milyon ton) Türkiye 3.6 milyon tonluk üretim ile Kanada (7.8 milyon ton) ve İtalya (5.0 milyon ton)'dan sonra Dünya'da makarnalık buğday üreten ülkeler arasında 3. ülke olmuştur (Pehlivan ve Ünver, 2017). Makarnalık buğday (T. durum), dünya pazarlarında yüksek fiyatla alıcı bulabilen bir üründür. Bunun en önemli nedeni, makarnalık buğdayın belli iklim ve toprak özellikleri gerektirmesi ve hammadde olarak kullanılacak ürünün sanayiciler tarafından hastalık ve zararlılardan etkilenmemiş olarak istenmesidir. Bu durum, makarnalık buğdayın geniş sınırlarda yetiştirilmesine engel olmaktadır. Buğday üretiminde son yıllarda artış görülmesine rağmen nüfus artışı ve buğdaya dayalı beslenme alışkanlıkları, bu bitkinin veriminin artırılmasını daha da zorunlu hale getirmektedir. Bu da ancak bölgelere göre en uygun çeşitlerin bulunması ve modern teknolojiler kullanılarak yetiştirme tekniklerinin uygulanması gibi ürün artırıcı tedbirlerin yanı sıra, hastalık zararlı ve yabancı otlara karşı etkili ve ekonomik savaşım yöntemlerinin uygulanmasıyla mümkün olabilmektedir.

Ülkemizde ve dünyada buğday üretimini sınırlayan biyotik faktörlerin başında külleme, septoria yaprak lekesi ve pas hastalıkları gelmektedir (Cowger 2018, Turgay 2016, Schwessinger 2017). Bunlardan Külleme hastalı̆ğ (Blumeria graminis (DC) E.O. Speer f. sp. tritici Em. Marchal (syn. Erysiphe graminis DC. f. sp. tritici Em. Marchal)) ekonomik olarak buğdayın en önemli hastalıklarından biri olup, \%34 ve üzerinde ürün kayiplarına neden olabilmektedir (Li ve ark. 2011, Alam ve ark. 2013, Cao ve ark. 2013, Shen ve ark. 2015). Külleme (E. graminis f. sp. tritici) ılıman ve yağışlı alanlarda sık görülen bir tahıl hastalı̆̆ılır. Fungus, bitki yaprakları üzerinde nokta şeklinde beyaz gri renkte püstüller halinde görülmektedir. Uygun koşullarda püstüller birleşmekte, yaprağın tamamını kaplayabilmekte, hatta sap ve başağa kadar ulaşabilmektedir (Kösem, 2004). Hastalık şiddetine ve bitkinin enfeksiyona maruz kaldığı gelişme dönemine bağlı olarak yapraklarda fotosentez oranını, asimilasyon indeksini düşürmekte ve sonuç olarak tane verim ve kalitesinin düşmesine neden olmaktadır (Samobor ve ark. 2006). Hastalıkla mücadelede kültürel önlemler yanında kimyasal mücadelede yaygın olarak kullanılmaktadır. Kimyasal mücadelede kullanılan fungisitler tohum ve yeşil aksam ilaçlaması şeklinde uygulanmaktadır. Ancak tohum uygulaması çoğunlukla sezon boyunca hastalı̆̆ kontrol etmede yeterli olamamaktadır. Diğger taraftan yeşil aksam uygulamaları ise ekonomik olmadığı için tercih edilmemektedir. Yine kimyasal mücadelenin çevre ve insan sağlığına olan olumsuz etkileri ve buna karşı toplumsal duyarlılığın artması bu patojenle mücadelede dayanıklı çeşit kullanımını ön plana çıkarmışıı (Yahiaoui ve ark. 2004, Xiao ve ark. 2013). Patojen ırklarına spesifik majör gen dayanıklılı̆̆ ve bu bağlamda bir çok dayanıklılık genleri (pm genleri) (örneğin pmla- pm47 gibi) belirlenmiş ve 1slah programlarında kullanılmıştır (Yahiaoui ve ark. 2004, Xiao ve ark. 2013). Ancak patojen yeni ırklar geliştirerek bu majör gen dayanıklılıklarını kırarak şiddetli enfeksiyonlara neden olabilmekte ve ürün kayıplarını artırmaktadır (McDonald ve Linde 2002). Bu nedenle yeni dayanıklılık kaynaklarının veya yeni dayanıklı çeşitlerin geliştirilmesi etmenle mücadelede büyük önem arz etmektedir.

$\mathrm{Bu}$ çalışma bazı yerel makarnalık buğday çeşitlerinden külleme hastalığına dayanıklı olanların belirlenmesi amacı ile yapılmıştır. Böylece bu hastalığa dayanıklılık konusunda yapılacak ıslah çalışmalarına ön hazırlık yapılmıştır.

\section{Materyal ve Metot}

\subsection{Bitki Materyali}

Araştırmada, bitki materyali olarak Ege Tarımsal Araştırma Enstitüsü (ETAE) tarafından farklı bölgelerden toplanmış olan 49 adet yerel makarnalık buğday çeşidi ve kontrol amacıyla Çeşit1252 (hassas), Gediz75 (hassas), Bezostaja-1 (hassas), Tahirova-2000 (dayanıklı) ve Sofu (hassas) buğday çeşitleri kullanılmıştır. Yerel makarnalık buğday çeşitlerinin Türkiye'de toplandıkları iller ve bilinen yerel isimleri Çizelge 1 'de verilmiştir. 
Tablo 1. Araştırmada kullanılan makarnalık buğday çeşitleri ve toplandı̆̆ iller

\begin{tabular}{|c|c|c|c|c|c|}
\hline Sira No & Kayıt No & Toplandığı İ & Sira No & Kayıt No & Toplandığı İl \\
\hline 1 & TR1926 & İzmir & 29 & TR 52841 & Denizli \\
\hline 2 & TR 3619 & Balıkesir & 30 & TR 55109 & Uşak \\
\hline 3 & TR 3626 & Balıkesir & 31 & TR 55120 & Kütahya \\
\hline 4 & TR 3670 & Denizli & 32 & TR 55133 & Kütahya \\
\hline 5 & TR 14862 & -- & 33 & TR 55173 & Kütahya \\
\hline 6 & TR 31634 & Mardin & 34 & TR 56108 & Türkiye \\
\hline 7 & TR 31729 & Şanlıurfa & 35 & TR 56132 & Türkiye \\
\hline 8 & TR 31738 & Siirt & 36 & TR 57129 & Antalya \\
\hline 9 & TR 31760 & Gaziantep & 37 & Ăg buğday1 & -- \\
\hline 10 & TR 33437 & Kırklareli & 38 & Beyaziye & -- \\
\hline 11 & TR 37094 & Çorum & 39 & Bintepe & -- \\
\hline 12 & TR 37405 & Çorum & 40 & Boğacak & -- \\
\hline 13 & TR 45305 & Yozgat & 41 & Çalıbasan & -- \\
\hline 14 & TR 46555 & Muğla & 42 & Hacihalil & -- \\
\hline 15 & TR 46847 & Hakkari & 43 & Havrani & -- \\
\hline 16 & TR 47931 & Şanlıurfa & 44 & İskenderiye & -- \\
\hline 17 & TR 47937 & Adryaman & 45 & Karakılçık & -- \\
\hline 18 & TR 47939 & Adiyaman & 46 & Menceki & -- \\
\hline 19 & TR 48339 & Manisa & 47 & Sorgül & -- \\
\hline 20 & TR 48343 & Muğla & 48 & Üveyik & -- \\
\hline 21 & TR 48346 & Aydın & 49 & Yerli sarı & -- \\
\hline 22 & TR 48903 & Adiyaman & \multicolumn{3}{|c|}{ Kontrol Çeşitler } \\
\hline 23 & TR 50456 & Adiyaman & 1 & Çeşit1252 & -- \\
\hline 24 & TR 50469 & Adiyaman & 2 & Gediz75 & -- \\
\hline 25 & TR 50475 & Adiyaman & 3 & Sofu & -- \\
\hline 26 & TR 52708 & Balıkesir & 4 & Bezostaja-1 & -- \\
\hline 27 & TR 52719 & Balıkesir & 5 & Tahirova-2000 & -- \\
\hline 28 & TR 52835 & Burdur & & & \\
\hline
\end{tabular}

\section{2. İnokulum Hazırlığı}

Denemede kullanılan bitki materyaline külleme hastalığını bulaştırmak amacıyla İzmir, Adapazarı, Samsun ve Tokat yörelerinden toplanan külleme sporlarının bir karışımı inokulum kaynağı olarak kullanılmış̦tır. Farklı bölgelerde buğday tarlalarında doğal olarak hastalığın oluşumuna neden olan bu spor karışımının, patojenin Türkiye'deki muhtemel ırklarını temsil ettiği kabul edilmiştir.

\subsubsection{Hastalık Bulaştırma ve Olgun Bitki Dayanıklılı̆̆ının Gözlenmesi}

Hastalık denemesi 55x35x7 cm ebatlarındaki $45^{\prime}$ lik çoklu viyollerde yapılmıştır. Her bir çoklu viyole kontrol bitkileri olarak Çeşit1252, Gediz75, Bezostaja-1, Tahirova-2000 ve Sofu çeşitleri yerleştirilmiştir. Saksılar 3:2:1 oranında tarla toprağı, yanmış koyun gübresi ve kalın kum içeren bir karışımla doldurulmuş ve hastalık değerlendirmesi için her bir genotipten 10-20 adet tohum ekilmiştir. Çimlenen tohumlar iki yapraklı döneme ulaşıncaya kadar, mevsime bağlı kalmaksızın hızlı bir şekilde büyütülerek hastalık bulaştırabilmek için, Gaziosmanpaşa Üniversitesi Ziraat Fakültesi Tarla bitkileri Bölümü tam otomatik kontrollü bitki yetiştirme serasında yetiştirilmiştir. Daha sonra fideler inokulasyon için $10{ }^{\circ} \mathrm{C}$ sıcaklık ve $\% 99$ neme sahip bir büyüme odasına alınmıştır. İnokulasyon ve inkübasyon işlemi çiğlendirme makinesinde ve bitki büyüme odasında yapılmıştır.

İnokulasyon için toplanan sporlar saf su içinde karıştırılarak spor süspansiyonu oluşturulmuş $\left(1 \times 10^{6}\right)$ ve çiğlendirme odasına bir gün önceden yerleştirilen bitkilerin üzerine püskürtülmüştür. Püskürtme işleminde tüm bitkilerin sporla bulaşmasına dikkat edilmiştir. Tam kontrollü otomatik bitki büyüme odası içine alınan bitkilere ise su püskürtüldükten sonra sporlar, ya enfekte olmuş bitkiler silkelenerek ya da toplanan sporlar kuru olarak püskürtülerek ikişer hafta aralıklarla sürekli bir bulaştırma yapılmıştır (Yang ve ark. 2017).

İnokulasyondan 7, 14 ve 21 gün sonra hastalık okuması yapılmış ve reaksiyon tipleri Leath ve Heun'un (1990) skalasına göre 0-9 arasında değişen değerlerle belirlenmiş̧ir. Bu skalaya göre $0=$ hiçbir enfeksiyon işaretinin bulunmadığı bağışıklılık, $1-3=$ dayanıklı ( $1=$ nekrozis olmadan küçük lekeler, $2=$ nekrozis, $3=$ misellerin görülmeye başladığı ve klorozisin başladığı evre), 4-6= klorotik alanların azalmasına karşıllk misel ve konidya üretimini azdan orta dereceye kadar arttığ intermediyer reaksiyon ve 7-9= misel ve konidyaların miktar ve yoğunluğunun sürekli arttığı hassas reaksiyon şeklinde değerlendirilmeye alınmıştır. Reaksiyon tipleri (D)= 0 
3 derecelerini kapsayan dayanıklılık, $(I)=4-6$ derecelerini kapsayan intermediyerlik ve $(H)=7-9$ derecelerini içeren hassasiyetlik olarak özetlendirilmiştir. Viyollerden hastalık oluşumları gözlemlenmiştir.

İlk denemede dayanıklı ve/veya tolerant olarak saptanan genotipler, ikinci defa gözleme tabi tutulmuştur. Ayrıca dayanıklı ve/veya tolerant olarak saptanan çeşitler saksılara şaşırtılarak serada büyümeye bırakılmış ve başaklanma döneminin sonuna kadar bu genotiplerde olgun bitki dayanıklılı̆̆ının olup olmadığı gözlemlenmiştir.

\section{Araştırma Sonuçları ve Tartışma}

$\mathrm{Bu}$ araştırmada buğdayın önemli gen kaynaklarından birisi olan yerel makarnalık buğday çeşitlerinden 49 adedinde külleme hastalı̆̆ına karşı genetik varyasyon incelenmiş ve yeni dayanıklılık gen(ler)inin varlığı araştırılmıştır.

İncelenen yerel makarnalık buğday çeşitlerinin ilk gelişme dönemi ve olgun bitki safhasında küllemeye dayanıklılıkları gözlemlenmiş ve reaksiyon şekilleri belirlenmiştir. Alınan gözlem sonuçları Çizelge 2'de verilmiştir.

Tablo 2. Araştırmada kullanılan makarnalık buğday çeşitlerinin isimleri, tohum kaynakları ve külleme hastalı̆̆ına gösterdikleri reaksiyon tipleri.

\begin{tabular}{|c|c|c|c|c|c|c|c|c|c|}
\hline \multirow[b]{2}{*}{$\begin{array}{l}\text { Sira } \\
\text { No }\end{array}$} & \multirow[b]{2}{*}{ Genotip } & \multirow[b]{2}{*}{$\begin{array}{c}\text { Toplandiğ } \\
\text { İl }\end{array}$} & \multicolumn{2}{|c|}{$\begin{array}{c}\text { Hastalık } \\
\text { Denemesi }\end{array}$} & \multirow[b]{2}{*}{$\begin{array}{c}\text { Sira } \\
\text { No }\end{array}$} & \multirow[b]{2}{*}{ Genotip } & \multirow[b]{2}{*}{$\begin{array}{c}\text { Toplandığı } \\
\text { İl }\end{array}$} & \multicolumn{2}{|c|}{$\begin{array}{c}\text { Hastalık } \\
\text { Denemesi }\end{array}$} \\
\hline & & & $\begin{array}{c}1 . \\
\text { Deneme }\end{array}$ & $\begin{array}{c}2 . \\
\text { Deneme }\end{array}$ & & & & $\begin{array}{c}1 . \\
\text { Deneme }\end{array}$ & $\begin{array}{c}2 . \\
\text { Deneme }\end{array}$ \\
\hline 1 & TR 1926 & İzmir & $\mathrm{H}$ & $\mathrm{H}$ & 28 & TR 52835 & Burdur & $\mathrm{H}$ & $\mathrm{H}$ \\
\hline 2 & TR 3619 & Balıkesir & $\mathrm{H}$ & $\mathrm{H}$ & 29 & TR 52841 & Denizli & $\mathrm{H}$ & $\mathrm{H}$ \\
\hline 3 & TR 3626 & Balıkesir & $\mathrm{H}$ & $\mathrm{H}$ & 30 & TR 55109 & Uşak & $\mathrm{H}$ & $\mathrm{H}$ \\
\hline 4 & TR 3670 & Denizli & $\mathrm{H}$ & $\mathrm{H}$ & 31 & TR 55120 & Kütahya & $\mathrm{H}$ & $\mathrm{H}$ \\
\hline 5 & TR 14862 & -- & $\mathrm{H}$ & $\mathrm{H}$ & 32 & TR 55133 & Kütahya & $\dot{\mathrm{I}}$ & $\mathrm{H}$ \\
\hline 6 & TR 31634 & Mardin & $\mathrm{H}$ & $\mathrm{H}$ & 33 & TR 55173 & Kütahya & $\mathrm{H}$ & $\mathrm{H}$ \\
\hline 7 & TR 31729 & Şanlıurfa & $\mathrm{D}$ & $\mathrm{D}$ & 34 & TR 55108 & Türkiye & $\mathrm{H}$ & $\mathrm{H}$ \\
\hline 8 & TR 31738 & Siirt & $\dot{\mathrm{I}}$ & $\mathrm{H}$ & 35 & TR 56132 & Türkiye & $\mathrm{H}$ & $\mathrm{H}$ \\
\hline 9 & TR 31760 & Gaziantep & $\dot{\mathrm{I}}$ & $\mathrm{H}$ & 36 & TR 57129 & Antalya & $\mathrm{H}$ & $\mathrm{H}$ \\
\hline 10 & TR 33437 & Kırklareli & $\mathrm{H}$ & $\mathrm{H}$ & 37 & Ağ Buğdayı & -- & $\mathrm{H}$ & $\mathrm{H}$ \\
\hline 11 & TR 37094 & Çorum & $\dot{\mathrm{I}}$ & $\mathrm{H}$ & 38 & Beyaziye & -- & $\dot{\mathrm{I}}$ & $\mathrm{H}$ \\
\hline 12 & TR 37405 & Çorum & $\mathrm{D}$ & $\mathrm{H}$ & 39 & Bintepe & -- & $\dot{\mathrm{I}}$ & $\mathrm{H}$ \\
\hline 13 & TR 45305 & Yozgat & $\mathrm{H}$ & $\mathrm{H}$ & 40 & Boğacak & -- & $\dot{\mathrm{I}}$ & $\mathrm{H}$ \\
\hline 14 & TR 46555 & Muğla & $\mathrm{H}$ & $\mathrm{H}$ & 41 & Çalıbasan & -- & $\dot{\mathrm{I}}$ & $\mathrm{H}$ \\
\hline 15 & TR 46847 & Hakkari & $\mathrm{H}$ & $\mathrm{H}$ & 42 & Hacıhalil & -- & $\dot{\mathrm{I}}$ & $\mathrm{H}$ \\
\hline 16 & TR 47931 & Şanlıurfa & $\mathrm{H}$ & $\mathrm{H}$ & 43 & Havrani & -- & $\dot{\mathrm{I}}$ & $\mathrm{H}$ \\
\hline 17 & TR 47937 & Adiyaman & $\mathrm{H}$ & $\mathrm{H}$ & 44 & İskenderiye & -- & $\mathrm{H}$ & $\mathrm{H}$ \\
\hline 18 & TR 47939 & Adıyaman & $\mathrm{H}$ & $\mathrm{H}$ & 45 & Karakılçık & -- & $\mathrm{H}$ & $\mathrm{H}$ \\
\hline 19 & TR 48339 & Manisa & $\mathrm{H}$ & $\mathrm{H}$ & 46 & Menceki & -- & $\mathrm{H}$ & $\mathrm{H}$ \\
\hline 20 & TR 48343 & Muğla & $\mathrm{D}$ & $\mathrm{H}$ & 47 & Sorgül & -- & $\mathrm{H}$ & $\mathrm{H}$ \\
\hline 21 & TR 48346 & Aydın & $\dot{\mathrm{I}}$ & $\mathrm{H}$ & 48 & Üveyik & -- & $\mathrm{H}$ & $\mathrm{H}$ \\
\hline 22 & TR 48903 & Adiyaman & $\mathrm{H}$ & $\mathrm{H}$ & 49 & Yerli Sar1 & -- & $\mathrm{D}$ & $\mathrm{H}$ \\
\hline 23 & TR 50456 & Adiyaman & $\mathrm{H}$ & $\mathrm{H}$ & 50 & Çeşit 1252 & -- & $\dot{\mathrm{I}}$ & $\mathrm{H}$ \\
\hline 24 & TR 50469 & Adiyaman & $\mathrm{H}$ & $\mathrm{H}$ & 51 & Gediz 75 & -- & $\dot{\mathrm{I}}$ & $\mathrm{H}$ \\
\hline 25 & TR 50475 & Adiyaman & $\dot{\mathrm{I}}$ & $\mathrm{H}$ & 52 & Sofu & -- & $\mathrm{H}$ & $\mathrm{H}$ \\
\hline 26 & TR 52708 & Balıkesir & $\mathrm{H}$ & $\mathrm{H}$ & 53 & Bezostaja & -- & $\dot{\mathrm{I}}$ & $\mathrm{H}$ \\
\hline 27 & TR 52719 & Balıkesir & $\mathrm{H}$ & $\mathrm{H}$ & 54 & $\begin{array}{c}\text { Tahirova- } \\
2000\end{array}$ & -- & $\dot{I}$ & $\dot{I}$ \\
\hline
\end{tabular}

D: Dayanıklı, H: Hassas, İ: İntermediyer

Hastalık gözlemine alınan 49 yerel çeşit içinden fide döneminde sadece birinde dayanıklılık görülmüştür. Yerel çeşitlerden 14 tanesi ilk denemede orta derece dayanıklı bulunmuş, ancak ikinci denemede yerel çeşitlerden sadece biri (TR 31729) dayanıklı reaksiyon göstermiştir (Çizelge 2). Beş kontrol bitkisinden sadece ekmeklik buğday çeşitlerinden Bezostaja-1 ve Tahirova-2000 orta derece dayanıklı bulunmuştur. Kontrol bitkilerinden Bezostaja-1 ve Tahirova-2000, yerel çeşitlerden ise TR 31729 ve Bintepe olgun bitki dayanıklılığının test edilmesi için saksılara şaşırtılarak serada büyümeye alınmışlardır.

Bu bitkilere serada sürekli hastalık sporu bulaştırarak olgun bitki dayanıklılığına sahip olup olmadıkları gözlemlenmiştir. Bintepe yerel çeşidi ve Bezostaja-1 kontrol çeşidi ilk denemede orta derece dayanıklı reaksiyona sahipken, ikinci denemede yoğun epidemi altında fide döneminde hassas reaksiyon göstermişlerdir. Bu çeşitlerin olgun bitki dayanıklılığına da sahip olmadıkları dolayısıyla e-ISSN : 2148-2683 
hassas oldukları belirlenmiştir. TR 31729 numaralı yerel çeşitte tek (majör) gen dayanıklılı̆̆ gözlenmiştir. Tahirova-2000 çeşidi ise yoğun epidemi altında olmasına rağmen, tipik olgun bitki dayanıklılığı özelliği göstermiştir. Alt yapraklarda bir miktar hastalık oluşumu gözlenmesine rağmen sporlar bayrak yaprağı ve başakta gelişememişlerdir.

Makarnalık buğdayın anavatanlarından biri olan Türkiye uygun ekolojisi nedeniyle dünyada kaliteli makarnalık buğday üretebilecek ülkelerin başında gelmektedir. Ancak istenen kalitede ve verimde üretim yapılabilmesi için mevcut çeşitlerin gerek hastalıklara dayanıklılık gerekse kalite bakımından 1slah edilmesi gerekmektedir (Yıldırım ve ark. 2019). Bu amaçla öncelikle buğdayda daralan genetik varyasyonun tekrar oluşturulması açısından, yetiştikleri yörelere uyum sağlamış, kendi içinde dahi genetik varyasyona sahip olan yerel çeşitler (Allard ve Bradshaw 1964) büyük bir öneme sahiptirler. Ayrıca yerel çeşitlerin birçok abiyotik ve biyotik stres faktörlerine karşı dayanıklılık genlerine sahip oldukları da belirlenmiştir (Hede ve ark. 1999, Hart 2001). Ülkemizde bugüne kadar yerli gen kaynaklarımızın yeterince karakterize edilmemiş olması da bu çalışmanın gerekliliğini ve önemini ortaya koymaktadır (Yıldırım ve ark. 2011).

Türkiye'de yetiştirilen mevcut makarnalık çeşitlerimizin büyük çoğunluğu küllemeye hassastır. Bunun en önemli nedeni sslah çalışmalarında pas hastalıkları gibi ekonomik olarak küllemeden daha önemli olan hastalıklara öncelik ve ağırlık verilmesidir. Oysa hastalığa uygun ekolojilerde külleme buğdayda \%13'den \%34'e varan oranlarda verim kaybına neden olabilmektedir (Griffey ve Das 1994, Yıldırım 2003). Verim kaybı yanında buğday danesinde ve samanında neden olduğu kalite kaybı da dikkate alındığında hastalığın önemi daha da artmaktadır.

Ülkemizde küllemeye dayanıklı olarak bilinen ve yaygın olarak üretilen çeşitlerden birisi Bezostaja-1'dir. Otuz yıldan daha uzun süredir üretimde olan bu çeşit, 1RS/1BL translokasyon kromozomu (çavdar/buğday) üzerinde bulunan Pm8 genine sahiptir (Wricke ve ark. 1996). Yapılan bu çalışma Bezostaja-1 çeşidinin hassas reaksiyon göstermesi üzerine, artık bu dayanıklılık geninin kırıldığı ve yeni virülens gen(ler)in etkili olduğu da ortaya çıkarılmıştır.

Powers ve Sando (1960) da ekmeklik buğday ve külleme patojeni arasındaki konukçu-patojen ilişkisini konu alan gene karşı gen hipotezini doğrulamışlardır. Bilinen direnç genlerine sahip hatları ayırt edebilen bir dizi külleme izolatı kullanarak, bitki gen kaynakları aksesyonlarında veya kültür bitkilerinde majör (tek) dayanıklılık genleri ve gen kombinasyonları varlığı teyit edilebilir.

Buğday-Haynaldia villosa translokasyonu 6VS/AL' dan Pm21 (Chen ve ark. 1995), Çin (Huang ve ark. 1997) ve Avrupa'da (Qi ve ark. 1996) var olan tüm külleme patojenlerine karşı direnç göstermektedir. Yapılan bir çalışmada Pm2 ve Pm21'e sıkıca bağlı olan veya Pm4a ile karşı1ıklı ayrılan RFLP markörleri kullanılarak, üç adet ikili-gen kombinasyonu (Pm2 + Pm4a, Pm2 + Pm21, Pm4a + Pm21) başarıyla elit bir buğday kültür bitkisi olan 'Yang158'e entegre edilmiştir (Liu ve ark. 2002).

\section{Sonuç}

Buğdayda şu ana kadar 50 lokusta tanımlanmış ve haritalanmış 78 adet dayanıklılık geni (PmI$P m 53, P m 18=P m 1 c, P m 22=P m 1 e, P m 23=P m 4 c, P m 31=P m 21)$ bulunmaktadır ve bunlardan 27 tanesi buğdayın yakın veya uzak akraba türlerinden aktarılmıştır (Sönmezoğlu ve ark. 2010; Elkot ve ark. 2015). Tanımlanan 50 lokustan 11'i buğdayın A genomuna, 26 tanesi B genomuna ve 13'ü D genomuna haritalanmıştır (Elkot ve ark. 2015). Buğdayda çalışılan küllemeye dayanıklılık genlerinin büyük çoğunluğu majör (tek) gen özelliği göstermektedir. Buğday ıslahında kullanılan gen sayının artırılması, ekonomik ve uzun süreli dayanıklılığın sağlanması açısından oldukça önemlidir. Dolayısıyla bu çalışmada majör (tek) gen dayanıklılı̆ına sahip olduğu saptanan TR 31729 numaralı yerel buğday çeşidi çok büyük bir önem arz etmektedir. Türkiye'deki mevcut külleme ırklarını temsil eden spor kokteyline karşı bu çeşidin dayanıklılığını sağlayan gen(ler)in daha önce kullanılmayan yeni bir gen(ler) olma ihtimali yüksektir.

Sonuç olarak, bu çalışmada belirlenen genetik varyasyon beklenenin çok altında çıkmış olsa da, yeni bir dayanıklılık gen kaynağının bulunmuş olması bile ileriye yönelik olarak ümit verici bir sonuçtur. Bu muhtemel yeni genin en kısa sürede genetik karakterizasyonu yapılarak, mevcut genlerden farklı olup olmadığı ortaya konulmalıdır. Yeni bir gen(ler) olduğunun belirlenmesi durumunda, yerel çeşitlerin buğdayla doğrudan melezlenebilmesi avantajından yararlanarak hızlı bir şekilde kültürü yapılan çeşitlere aktarılması mümkün olacaktır.

\section{Kaynakça}

Alam, M. A., Wang, C., \& Ji, W. (2013). Chromosomal location and SSR markers of a powdery mildew resistance gene in common wheat line N0308. African journal of Microbiology Research, 7(6), 477-482.

Allard, R. W., \& Bradshaw, A. D. (1964). Implications of genotype-environmental interactions in applied plant breeding 1. Crop science, 4(5), 503-508.

Cao, X., Luo, Y., Zhou, Y., Duan, X., \& Cheng, D. (2013). Detection of powdery mildew in two winter wheat cultivars using canopy hyperspectral reflectance. Crop Protection, 45, 124-131.

Chen, P. D., Qi, L. L., Zhou, B., Zhang, S. Z., \& Liu, D. J. (1995). Development and molecular cytogenetic analysis of wheatHaynaldia villosa 6VS/6AL translocation lines specifying resistance to powdery mildew. Theoretical and Applied Genetics, 91(67), 1125-1128.

Clarke J., Marchylo, B., Noll, J., \& Mc Caig, T (1996). The Screening of Durum Wheats for Pasta Quality: The Canadian System. 5th International Wheat Conference Abstracts, 10-14 Haziran 1996, 233-234 s., Ankara. 
Cowger, C., Mehra, L., Arellano, C., Meyers, E., \& Murphy, J. P. (2018). Virulence differences in Blumeria graminis f. sp. tritici from the central and eastern United States. Phytopathology, 108(3), 402-411.

Demir, İ., Yüce, S., Bilgen, G., Tanyolaç, B., Oğuz, \& İ. (1999). Bazı Genotiplerin Tanımlanmasında DNA Parmak İzlerinin Kullanılması Üzerinde Araştırmalar. Ege Üniversitesi, DTP Proje No:97 K120900, Bornova-İzmir.

Elkot, A. F. A., Chhuneja, P., Kaur, S., Saluja, M., Keller, B., \& Singh, K. (2015). Marker assisted transfer of two powdery mildew resistance genes PmTb7A. 1 and PmTb7A. 2 from Triticum boeoticum (Boiss.) to Triticum aestivum (L.). PloS one, 10(6), e0128297.

Geçit, H. H., Çiftçi, C. Y., Emeklier, Y., İkinci Karakaya, S. Ü., Adak, M. S., Kolsarıcı, Ö., Ekiz, H., Altınok, S., Sancak, C., Sevimay, C. S., \& Kendir, H. (2009). Tarla Bitkileri. Ankara Üniversitesi Ziraat Fakültesi Yayınları, Yayın No: 1569, Ders Kitabı: 521.

Griffey, C. A., \& Das, M. K. (1994). Inheritance of adult-plant reistance to powdery mildew in Knox 62 and Massey winter wheats. crop science, 34(3), 641-646.

Hart, G. E. (2001). Molecular-marker maps of the cultivated wheats and other Triticum species. In DNA-Based Markers in Plants (pp. 421-441). Springer, Dordrecht.

Heaney, S. P., Hall, A. A., Davies, S. A., \& Olaya, G. (2000). Resistance to fungicides in the Qol-STAR cross-resistance group: current perspectives. In The BCPC Conference: Pests and diseases, Volume 2. Proceedings of an international conference held at the Brighton Hilton Metropole Hotel, Brighton, UK, 13-16 November 2000 (pp. 755-762). British Crop Protection Council.

Hede, A. R., Skovmand, B., Reynolds, M. P., Crossa, J., Vilhelmsen, A. L., \& Stølen, O. (1999). Evaluating genetic diversity for heat tolerance traits in Mexican wheat landraces. Genetic Resources and Crop Evolution, 46(1), 37-45.

Singrün, C., Rauch, P., Morgounov, A., Hsam, S., \& Zeller, F. (2004). Identification of powdery mildew and leaf rust resistance genes in common wheat (Triticum aestivum L.). Wheat varieties from the Caucasus, Central and Inner Asia. Genetic resources and crop evolution, 51(4), 355-370.

Kösem S (2004). Önemli Tahıl Hastalıkları Zararlıları ve Mücadelesi Edirne Ticaret Borsası (http://wwwetborgtr/hastaliklar htm).

Heun, M., Friebe, B., \& Bushuk, W. (1990). Chromosomal location of the powdery mildew resistance gene of Amigo wheat. Phytopathology, 80(10), 1129-1133.

Hong-Jie, L. I., Xiao-Ming, W. A. N. G., Feng-Jing, S. O. N. G., Cui-Ping, W. U., Xiao-Fei, W. U., Zhang, N., ... \& ZHANG, X. Y. (2011). Response to powdery mildew and detection of resistance genes in wheat cultivars from China. Acta Agronomica Sinica, 37(6), 943-954.

Liu, Z., Sun, Q., Ni, Z., Nevo, E., \& Yang, T. (2002). Molecular characterization of a novel powdery mildew resistance gene Pm30 in wheat originating from wild emmer. Euphytica, 123(1), 21-29.

McDonald, B. A., \& Linde, C. (2002). Pathogen population genetics, evolutionary potential, and durable resistance. Annual review of phytopathology, 40(1), 349-379.

Ovesna, J. ., Kucera, L., Bockova, R., \& Holubec, V. (2002). Characterisation of powdery mildew resistance donors within Triticum boeoticum accessions using RAPDs. Czech journal of genetics and plant breeding, 38(3/4), 117-124.

Pehlivan, A., \& Ünver, S.İ. (2017). Makarnalık Buğdayda Kalite Islahı Çalışmaları. Tarla bitkileri merkez araştırma enstitüsü dergisi, 26(1), 127-151.

Powers, H., \& Sando, W. J. (1960). Genetic control of the host-parasite relationship in Wheat powdery mildew. Phytopathology, 50(6).

Qi, L., Cao, M., Chen, P., Li, W., \& Liu, D. (1996). Identification, mapping, and application of polymorphic DNA associated with resistance gene Pm21 of wheat. Genome, 39(1), 191-197.

Samobor, V., Vukobratović, M., \& Jošt, M. (2006). Effect of powdery mildew attack on quality parameters and experimental bread baking of wheat. Acta Agric. Slov, 87, 381-391.

Schwessinger, B. (2017). Fundamental wheat stripe rust research in the 21st century. New Phytologist, 213(4), 1625-1631.

Sönmezoğlu, Ö. A., Yıldırım, A., Güleç, T. E., \& Kandemir, N. (2010). Markör Destekli Seleksiyonun Buğday Islahında Kullanımı. Gaziosmanpaşa Üniversitesi Ziraat Fakültesi Dergisi, 2010(1), 105-112.

Shen, X. K., Ma, L. X., Zhong, S. F., Liu, N., Zhang, M., Chen, W. Q., ... \& Bai, G. H. (2015). Identification and genetic mapping of the putative Thinopyrum intermedium-derived dominant powdery mildew resistance gene PmL962 on wheat chromosome arm 2BS. Theoretical and applied genetics, 128(3), 517-528.

Turgay, E. B., Büyük, O., Ölmez, F., Yıldırım, A. F., \& Zafer, M. E. R. T. İç Anadolu Bölgesinde Buğdayda Septorya yaprak lekesi hastalı̆̆ının [Zymoseptoria tritici (Desm. Quaedvlieg \& Crous)] yaygınlığının belirlenmesi ve moleküler tanılanması. Bitki Koruma Bülteni, 56(3).

USDA (2017). World Agricultural Production. https://appsfasusdagov/psdonline/ circulars/productionpdf.

Wricke, G., Dill, P., \& Senft, P. (1996). Linkage between a major gene for powdery mildew resistance and an RFLP marker on chromosome 1R of rye. Plant breeding, 115(1), 71-73.

Xiao, M., Song, F., Jiao, J., Wang, X., Xu, H., \& Li, H. (2013). Identification of the gene Pm47 on chromosome 7BS conferring resistance to powdery mildew in the Chinese wheat landrace Hongyanglazi. Theoretical and Applied Genetics, 126(5), 1397. 1403.

Yahiaoui, N., Srichumpa, P., Dudler, R., \& Keller, B. (2004). Genome analysis at different ploidy levels allows cloning of the powdery mildew resistance gene Pm3b from hexaploid wheat. The Plant Journal, 37(4), 528-538.

Yıldırım, A., Sakin, M., Karadag, Y., Gokmen, S., Kandemir, N., Akkaya, M. S., \& Yıldırım, F. (2004). Genetic marker mediated transfer of an alien gene, Pm21, into wheat conferring resistance to powdery mildew. Biotechnology \& Biotechnological Equipment, 18(2), 15-19.

Yıldırım, A., Ateş Sönmezoğlu, Ö., Gökmen, S., Kandemir, N., Aydın, N. (2011). Determination of Genetic Diversity among Turkish Durum Wheat Landraces by Microsatellites. African Journal of Biotechnology. 10 (19), 3915-3920. 
Yıldırım, A., Ateş Sönmezoğlu, Ö., Sayaslan, A., Kandemir, N., Gökmen, S. (2019). Molecular Breeding of Durum Wheat for Pasta Quality. Quality Assurance and Safety of Crops \& Foods, 11(1), 15-21.

Yang, L., Zhang, X., Zhang, X., Wang, J., Luo, M., Yang, M., \& Fu, D. (2017). Identification and evaluation of resistance to powdery mildew and yellow rust in a wheat mapping population. PloS one, 12(5), e0177905. 